J. Clin. Chem. Clin. Biochem.

Vol. 24, 1986, pp. 103-106

(C) 1986 Walter de Gruyter \& Co.

Berlin - New York

\title{
Drug Interference with Urine Protein Determination
}

\author{
By Shimona Yosselson-Superstine and Yeheskel Sinai
}

Department of Pharmacy, School of Pharmacy Hebrew University of Jerusalem, Jerusalem, Israel

(Received November 20, 1984//Juni 27/October 16, 1985)

Summary: The purpose of this study was to detect the possibility of drug interference in the estimation of urine protein in patients receiving therapeutic doses of penicillin G, ampicillin, methicillin, cefoxitin, cefazolin, gentamicin, co-trimoxazole, phenothiazines, glibenclamide and acetazolamide. Five different methods for urine protein determination were compared in these patients, when different amounts of albumin were added to urine in vitro, and in a control group of patients not treated with drugs known to interfere with these methods. The techniques included two semi-quantitative tests - a strip test (Albustix) and heat and acetic acid turbidity test; and three quantitative tests - sulphosalicylic acid test, trichloroacetic acid test and a test based on a formation of Ponceau S dye-protein complex (Urin-Pak).

The only significant interference found was that of gentamicin with the Ponceau S dye test.

\section{Interferenz von Arzneimitteln mit der Bestimmung von Proteinen im Harn}

Zusammenfassung: Die Bestimmung von Protein im Harn sollte hinsichtlich möglicher Interferenzen bei Patienten geprüft werden, die therapeutische Dosen von Penicillin G, Ampicillin, Methicillin, Cefoxitin, Cefazolin, Gentamicin, Co-trimoxazol (Trimethoprim/Sulfamethoxazol), Phenothiazine, Glibenclamid und Acetazolamid erhielten. Am Harn dieser Patienten wurden 5 verschiedene Methoden zur Proteinbestimmung verglichen, indem unterschiedliche Mengen von Albumin in vitro zum Harn hinzugefügt wurden. Als Kontrollen dienten Harne von Patienten, die nicht mit Arzneimitteln, von denen Interferenzen mit den Methoden bekannt waren, behandelt wurden.

Die Methoden umfaßten żwei halbquantitative Tests: einen Streifentest (Albustix) und den Hitze/EssigsäureTrübungstest sowie drei quantitative Tests: Sulfosalicylsäuretest, Trichloressigsäuretest und einen Test auf Grundlage dèr Bildung eines Ponceau S Farbstoff-Protein-Komplexes (Urin-Pak).

Die einzige signifikante Interferenz wurde für Gentamicin mit dem Ponceau S Farbstofftest gefunden.

\section{Introduction}

Various drugs have been reported to interfere with various methods of urine protein measurement (1). However, many of these reports were based on in vitro studies and with drug concentrations above those normally achieved in clinical practice, thus the clinical significance of these interferences is not always clear. Moreover, the interfering agents as reported in many cases in the literature, were designated by the family of drugs (e. g., cephalosporins, sulphon- amides, sulphonylureas) and the relevance to newly introduced agents of the same family remains in question. The purpose of this study was to compare five different methods for the estimation of urine protein which are used in clinical practice

a) in vitro,

b) in a control group of patients, and

c) in patients receiving therapeutic doses of various medications suspected, according to the literature, to interfere with at least one of the methods. 
It was assumed that albuminuria caused by disease or by a nephrotoxic effect of a drug would be detected by all methods, whereas false albuminuria caused by a drug interference with the methodology of a test would be recognised by significantly different values from the different methods. No single method can be considered as a reference test, since the techniques employed may respond differently to different types of protein and may be interferred with by high concentration of urinary pigments.

\section{Materials and Methods}

The five different tests for the estimation of urine protein were carried out according to published procedures. The tests were as follows:

A. Two semi-quantitative tests:

1. A strip test - "Albustix" (2),

2. Heat and acetic acid turbidity test (3).

B. Three quantitative tests:

1. Sulphosalicylic acid test (4),

2. Trichloroacetic acid test (5),

3. Ponceau S dye-protein complex test - "Urin-Pak" $(6,7)$.

All readings were made by one observer. All the analyses were done on the same urine samples.

The upper limit of "normal" urinary protein for Ponceau S dye was $0.3 \mathrm{~g} / \mathrm{l}$ and $0.15-0.2 \mathrm{~g} / \mathrm{l}$ for the other four methods.

\section{In vitro studies}

Albumin (Albumin buman 4X Crystalline, Nutritional Biochemicals Corporation, Cleveland, Ohio) in concentrations of $0,0.1,0.5$ and $1.0 \mathrm{~g} / \mathrm{l}$ was added to urine samples of one healthy volunteer on different days. The samples were then analysed for protein in order to determine the precision of each method and to compare the methods. These protein estimates were not used for calculation of protein concentrations in patients. Patient protein concentrations were calculated from separate standard curves, or from an albumin standard run in each day of analysis according to the method's published instructions.

\section{Study population}

Seventy nine hospitalized adult patients receiving parenterally therapeutic doses of the following medications: penicillin $G$; ampicillin, methicillin, cefoxitin, cefazolin, and gentamicin; and orally therapeutic doses of co-trimoxazole, phenothiazines, (chlorpromazine or trifluoperazine), glibenclainide and acetazolamide. Details about dosage schedule and duration of treatment are given in table 1 . Patients who had received radioopaque dyes which could interfere with some methods or with a disease like multiple myeloma or conditions which could cause excretion of proteins other than albumin, were not included in the study. None of the various other medications received by the patients was reported to interfere with urine protein determination.

\section{Mode of urine collection}

On the day before urine collection, patients were given a disposable container and were instructed to void into it their first urine specimen, between 7 and 8 hours in the morning. $\mathrm{pH}$ was
Tab. 1. Dosage and duration of administration of studied drugs.

\begin{tabular}{|c|c|c|c|c|}
\hline \multirow[t]{2}{*}{ Drug } & \multirow[t]{2}{*}{ Dosage } & \multirow{2}{*}{$\begin{array}{l}\text { Num- } \\
\text { ber } \\
\text { of } \\
\text { pa- } \\
\text { tients. }\end{array}$} & \multicolumn{2}{|c|}{$\begin{array}{l}\text { Duration of } \\
\text { treatment }\end{array}$} \\
\hline & & & $\begin{array}{l}\text { Mean } \\
\text { (days) }\end{array}$ & $\begin{array}{l}\text { Range } \\
\text { (days) }\end{array}$ \\
\hline Ampicillin & $\begin{array}{l}1.5 \mathrm{~g} \times 4 \\
2.0 \mathrm{~g} \times 4\end{array}$ & $\begin{array}{l}6 \\
2\end{array}$ & $\begin{array}{l}5 \\
6\end{array}$ & $\begin{array}{l}(4-7) \\
(5-6)\end{array}$ \\
\hline Cefazolin & $\begin{array}{l}1.0 \mathrm{~g} \times 3 \\
1.0 \mathrm{~g} \times 4\end{array}$ & $\begin{array}{l}8 \\
1\end{array}$ & $\begin{array}{l}6 \\
7\end{array}$ & $(2-9)$ \\
\hline Cefoxitin & $\begin{array}{l}2.0 \mathrm{~g} \times 3 \\
2.0 \mathrm{~g} \times 4\end{array}$ & $\begin{array}{l}3 \\
1\end{array}$ & $\begin{array}{r}6 \\
12\end{array}$ & $(5-6)$ \\
\hline Co-trimoxazole & 2 tablets $\times 2$ & 4 & 8 & $(5-13)$ \\
\hline $\begin{array}{l}\text { Methicillin + } \\
\text { Penicillin }\end{array}$ & $\begin{array}{l}1.5 \text { or } 2.0 \mathrm{~g} \times 4 \\
1500000 \text { or } \\
3000000 \times 4\end{array}$ & 4 & 4 & $(3-8)$ \\
\hline $\begin{array}{l}\text { Methicillin + } \\
\text { Glibenclamide }\end{array}$ & $\begin{array}{l}1.5 \text { or } 2.5 \mathrm{~g} \times 4 \\
5 \mathrm{mg} \times 1 \text { or } 2\end{array}$ & 6 & 5 & $(2-12)$ \\
\hline Acetazolamide & $\begin{array}{l}250 \mathrm{mg} \times 3 \\
250 \mathrm{Mg} \times 4\end{array}$ & $\begin{array}{l}3 \\
2\end{array}$ & $\begin{array}{l}79 \\
22\end{array}$ & $\begin{array}{l}(8-210) \\
(8-35)\end{array}$ \\
\hline Glibenclamide & $\begin{array}{l}5 \mathrm{mg} \times 1 \\
5 \mathrm{mg} \times 2 \\
5 \mathrm{mg} \times 3\end{array}$ & $\begin{array}{l}4 \\
7 \\
1\end{array}$ & $\begin{array}{r}6 \\
25 \\
8\end{array}$ & $\begin{array}{l}(2-9) \\
(7-60)\end{array}$ \\
\hline Penicillin & $2000000 \times 4$ & 5 & 6 & $(3-10)$ \\
\hline Chlorpromazine & $25 \mathrm{mg} \times 2$ & 2 & 8 & $(7-9)$ \\
\hline Trifluoperazine & $\begin{array}{l}10 \mathrm{mg} \times 2 \\
10 \mathrm{mg} \times 3\end{array}$ & $\begin{array}{l}1 \\
1\end{array}$ & $\begin{array}{l}10 \\
20\end{array}$ & \\
\hline Gentamicin & $\begin{array}{r}60 \mathrm{mg} \times 3 \\
80 \mathrm{mg} \times 3 \\
100 \mathrm{mg} \times 3\end{array}$ & $\begin{array}{l}1 \\
4 \\
2\end{array}$ & $\begin{array}{l}7 \\
6 \\
7\end{array}$ & $(2-9)$ \\
\hline $\begin{array}{l}\text { Gentamicin }+ \\
\text { Ampicillin }\end{array}$ & $\begin{array}{l}80 \text { or } \\
100 \mathrm{mg} \times 3 \\
1.5 \text { or } 2.0 \mathrm{~g} \times 4\end{array}$ & $\begin{array}{l}9 \\
\ddots \quad:\end{array}$ & 5 & $(2-10)$ \\
\hline $\begin{array}{l}\text { Gentamicin + } \\
\text { Cefazolin }\end{array}$ & $\begin{array}{l}100 \mathrm{mg} \times 3 \\
1.0 \mathrm{~g} \times 3\end{array}$ & 2 & 6 & \\
\hline
\end{tabular}

determined immediately upon collection of the samples and they were refrigerated until half an hour before protein measurement, later the same day. Different aliquots of urine were taken from the specimens depending on the test procedure. They ranged from $0.1 \mathrm{ml}$ for the Ponceau $S$ dye test to $5 \mathrm{ml}$ for the heat and acetic acid test.

\section{Control group}

Sixteen hospitalized adult patients not receiving any of the above medications or other medications known to affect urine protein determination.

\section{Statistics}

Urine protein values obtained by the different methods were compared by a method of analysis of variance with repeated measurements (8), using the BDMP program (9). When it was found that at least one significant difference between two paired means exists $(p<0.05)$, a further analysis with $t$ test for paired samples was carried out to identify the significantly different
pair. 


\section{Results and Discussion}

\section{Comparison of the methods in vitro}

Table 2 demonstrates that the 3 quantitative methods for the estimation of urine protein are comparable. No significant difference among the mean values obtained with these methods was found when $0,0.1$ and $0.5 \mathrm{~g} / 1$ of albumin were added. There was however, a tendency for the Ponceau $S$ dye method to give false positive values in urine to which no protein was added and a tendency of the sulphosalicylic acid method to give higher readings with $1.0 \mathrm{~g} / \mathrm{l}$ of albumin (mean 1.05 versus 0.96 for trichloroacetic acid and 0.95 for Ponceau $S$ dye, $P<0.05$ ). The Ponceau $S$ dye method was the most precise at this protein level $(\mathrm{CV}=4.3 \%)$.

\section{Comparison of the methods in control group}

The means of urine protein by the sulphosalicylic acid, trichloroacetic acid and Ponceau $S$ dye methods in the control group of patients did not differ significantly $P>0.05$. The difference did not vary even when the 3 patients with grades 2 and 3 of protein, as determined by the semi-quantitative methods, were excluded from analysis.
Comparison of the methods in patients receiving certain medications

The means of the determinations of urine protein values in patients receiving ampicillin, cefazolin, cefoxitin, co-trimoxazole and methicillin (in combination with penicillin $G$ or glibenclamide), were not found to be statistically different in the 3 quantitative methods. As can be seen in table 3 , in patients receiving therapeutic doses of acetazolamide, glibenclamide, penicillin $\mathrm{G}$ and phenothiazines, urine protein determination by the 3 quantitative methods differed significantly.

The differences arose from the Ponceau $S$ dye method (c), which gave higher readings than those obtained by the sulphosalicylic acid method (a), or (except for the cases of glibenclamide and gentamicin) the trichloroacetic method (b). Most of the protein concentrations in the urine sample of patients receiving these drugs remained in the $0-0.15 \mathrm{~g} / \mathrm{l}$ range and thus the differences cannot be considered clinically relevant. There were few individual concentrations exceeding this range up to $0.25 \mathrm{~g} / 1$ by the Ponceau $\mathrm{S}$ dye method, but this still remained within the upper limit of "normal" urinary protein for this method. This does not exclude relevant clinical differences in patients with proteinuria.

Tab. 2. Interassay statistics for sulphosalicylic acid, trichloroacetic acid and Ponceau S dye methods for 7 different determinations.

\begin{tabular}{|c|c|c|c|c|c|c|c|c|c|c|}
\hline \multirow{2}{*}{$\begin{array}{l}\text { Albu- } \\
\text { min } \\
\text { added }\end{array}$} & \multicolumn{3}{|c|}{$\begin{array}{l}\text { Sulpho- } \\
\text { salicylic acid }\end{array}$} & \multicolumn{3}{|c|}{$\begin{array}{l}\text { Trichloroacetic } \\
\text { acid }\end{array}$} & \multicolumn{3}{|c|}{ Ponceau S dye } & $P$ \\
\hline & $\begin{array}{l}\text { Mean } \\
(\mathrm{g} / \mathrm{l})\end{array}$ & $\begin{array}{l}\text { Range } \\
(\mathrm{g} / \mathrm{l})\end{array}$ & $\begin{array}{l}\text { CV } \\
(\%)\end{array}$ & $\begin{array}{l}\text { Mean } \\
(\mathrm{g} / \mathrm{l})\end{array}$ & $\begin{array}{l}\text { Range } \\
(\mathrm{g} / \mathrm{l})\end{array}$ & $\begin{array}{l}\text { CV } \\
(\%)\end{array}$ & $\begin{array}{l}\text { Mean } \\
(\mathrm{g} / \mathrm{l})\end{array}$ & $\begin{array}{l}\text { Range } \\
(\mathrm{g} / \mathrm{l})\end{array}$ & $\begin{array}{l}\text { CV } \\
(\%)\end{array}$ & \\
\hline $\begin{array}{l}0 \\
0.1 \\
0.5 \\
1.0\end{array}$ & $\begin{array}{l}0 \\
0.09 \\
0.45 \\
1.05\end{array}$ & $\begin{array}{c}0-0 \\
0.09-0.10 \\
0.41-0.48 \\
0.95-1.10\end{array}$ & $\begin{array}{l}0 \\
5.7 \\
6.0 \\
5.2\end{array}$ & $\begin{array}{l}0 \\
0.09 \\
0.50 \\
0.96\end{array}$ & $\begin{array}{c}0-0 \\
0.08-0.12 \\
0.43-0.59 \\
0.87-1.09\end{array}$ & $\begin{array}{c}0 \\
17.2 \\
12.0 \\
8.9\end{array}$ & $\begin{array}{l}0.003 \\
0.10 \\
0.50 \\
0.95\end{array}$ & $\begin{array}{l}0-0.01 \\
0.09-0.12 \\
0.48-0.55 \\
0.89-1.00\end{array}$ & $\begin{array}{r}170.8 \\
9.4 \\
5.5 \\
4.3\end{array}$ & $\begin{array}{l}\text { NS* } \\
\text { NS } \\
\text { NS } \\
<0.05\end{array}$ \\
\hline
\end{tabular}

* NS = Not significant

Tab. 3. Mean and standard deviation of urine protein $(\mathrm{g} / \mathrm{l})$ measurements by sulphosalicylic acid, trichloroacetic acid and Ponceau $\mathrm{S}$ dye methods in patients receiving various drugs.

\begin{tabular}{|c|c|c|c|c|c|}
\hline Drug & $\begin{array}{l}\text { Patients } \\
\text { (N) }\end{array}$ & $\begin{array}{l}\text { a } \\
\text { Sulphosalicylic } \\
\text { acid }\end{array}$ & $\begin{array}{l}\text { b } \\
\text { Trichloroacetic } \\
\text { acid }\end{array}$ & $\begin{array}{l}\text { C } \\
\text { Ponceau S } \\
\text { Dye }\end{array}$ & $\mathbf{P}$ \\
\hline $\begin{array}{l}\text { Acetazolamide } \\
\text { Glibenclamide } \\
\text { Penicillin } \\
\text { Phenothazine } \\
\text { Gentamicin } \\
\text { Gentamicin + Ampicillin }\end{array}$ & $\begin{array}{r}5 \\
12 \\
5 \\
4 \\
7 \\
9\end{array}$ & $\begin{array}{c}0 \pm 0 \\
0.04 \pm 0.06 \\
0.03 \pm 0.04 \\
0.01 \pm 0.03 \\
0.13 \pm 0.16 \\
0.34 \pm 0.37\end{array}$ & $\begin{array}{l}0 \pm 0 \\
0.10 \pm 0.11 \\
0.02 \pm 0.02 \\
0.04 \pm 0.05 \\
0.43 \pm 0.51 \\
0.69 \pm 0.58\end{array}$ & $\begin{array}{l}0.04 \pm 0.03 \\
0.16 \pm 0.09 \\
0.14 \pm 0.04 \\
0.14 \pm 0.02 \\
2.60 \pm 2.60 \\
2.20 \pm 1.38\end{array}$ & $\begin{array}{l}<0.05(\mathrm{a}, \mathrm{c} ; \mathrm{b}, \mathrm{c})^{*} \\
<0.01(\mathrm{a}, \mathrm{c}) \\
<0.01(\mathrm{a}, \mathrm{c} ; \mathrm{b}, \mathrm{c}) \\
<0.01(\mathrm{a}, \mathrm{c} ; \mathrm{b}, \mathrm{c}) \\
<0.05(\mathrm{a}, \mathrm{c}) \\
<0.01(\mathrm{a}, \mathrm{c} ; \mathrm{b}, \mathrm{c})\end{array}$ \\
\hline
\end{tabular}

* The $a, b, c$, indices indicate the corresponding comparisons. 
Gentamicin was the only drug which caused a relevant statistical and clinical effect leading to a reading of very high values of protein by the Ponceau $S$ dye method. This verifies the results of Lievens \& Celis (10) who studied the possible interference of gentamicin with the Ponceau S dye method. They found that at therapeutic concentrations gentamicin gave an apparent proteinuria with protein-free urine and increased the results by a factor of 2 to 4 when proteins were present. They did not find interference of gentamicin with a turbidimetric method, using sulphosalicylic acid or trichloroacetic acid. Lievens \& Celis suggested that the precipitation of an insoluble salt of aminoglycosides with Ponceau $\mathrm{S}$ dye is the cause of the interference. They were able to eliminate the interference by changing the method slightly, precipitating urinary proteins first with trichloroacetic acid without Ponceau S dye (instead of with a mixture

\section{References}

1. Yosselson-Superstine, S. (1983) Drugs causing interference with laboratory tests. In: Iatrogenic Diseases Update 1983, 2nd edition (D'Arcy, P. F. \& Griffin, J. P., eds.) Oxford University Press, Oxford, pp. 214-217.

2. "Albustix". Product Information, Ames Co. Division of Miles Laboratories, Ltd., Stoke Poges, Slough 2L2 4LY, England.

3. Free, A. H., Rupe, C. O. \& Meltzer, I. (1957) Clin. Chem. 3, 716-727.

4. Bradley, M., Schumann, G. B. \& Ward, P. C. J. (1979) Examination of urine. In: Clinical Diagnosis and Management by Laboratory Methods, 16th ed. (Henry, J. B., ed.) W. B. Saunders Company, Philadelphia, PA., pp. 604-605. of the two), discarding the supernatant and then carrying out the original procedure on the precipitated protein redissolved in $\mathrm{NaOH}$.

None of the semi-quantitative methods was found to be affected by the drugs under stuiqy. Particularly noteworthy is the lack of effect of a drug causing alkaluria (acetazolamide) on urine protein estimation by the Albustix method. This test is known to give false positive results in a very alkaline urine (11), however, none of the patients had a urine $\mathrm{pH}$ of 10 or above. We conclude that methods other than Ponceau S dye for estimating urine protein should be used in patients receiving gentamicin therapy. Penicillin $\mathrm{G}$, co-trimoxazole, glibenclamide, acetazolamide and phenothiazines, contrary to suggestions in literature (1), were not shown to have a clinically relevant effect on any of the studied tests.

5. Bauer, J. C., Ackermann, P. G. \& Toro, G. (1974) Clinical Laboratory Methods, 8 th ed., C. V. Mosby, St. Louis, pp. 410-411.

6. "Urin-Pak". product Information, Ames Co., Miles Italiana S. P. A. 20040 Cavebago B, Milano; Italy.

7. Pesce, M. A. \& Strande, C. S. (1973) Clin. Chem. 19, 1265.

8. Winer, B. J. (1971) Statistical Principles in Experimental Design, 2nd ed. McGraw Hill Inc., pp. 261 - 282.

9. BMOP Statistical Software, University of California Press, Los Angeles, 1981.

10. Lievens, M. M. \& Celis, P. J. (1982) Clin. Chem. 28, 2328.

11. Gyure, W. (1977) Clin. Chem. 23, 876.

Dr. Shimona Yosselson ${ }_{3}$ Superstine Department of Pharmacy

School of Pharmacy P. O. B. 12065

The Hebrew University of Jerusalem

Jerusalem 91120 Israel 